International Journal of Advancement in Life Sciences Research

Online ISSN: 2581-4877

journal homepage http://ijalsr.org

Review Article

\title{
Role of Biological Nitrogen Fixation (BNF) in Sustainable Agriculture: A Review
}

\author{
Rittwika Mukherjee ${ }^{1}$, Supatra Sen ${ }^{2 \star}$ \\ ${ }^{1}$ Department of Environmental Science, Asutosh College, Kolkata-700026, India \\ ${ }^{2}$ Department of Botany, Asutosh College, Kolkata -700026, India
}

${ }^{*}$ Correspondence E-mail : supatrasen@gmail.com

\begin{abstract}
Agriculture has an enormous environmental footprint. One of the best ways to mitigate climate change is to create balanced food systems based on sustainable agriculture. To reduce the chemical dependence scientists are engineering crop plants for $\mathrm{N}_{2}$ fixation and they are focused on the biological process BNF (Biological Nitrogen Fixation) for the needs of $\mathrm{N}_{2}$ for crop plant soils. $\mathrm{N}_{2}$ fixed by the BNF process reduces the production cost, Green House gas (GHG) emissions, pollution of surface and ground water. Several management practices are there which influence BNF process in agricultural system. They are $\mathrm{N}$ - fertilization species genotype and cultivar and seeding ratios. Better management practices can help to improve $\mathrm{N}_{2}$ fixation. This review highlights the agro-economic importance of BNF and shows it as a cost effective, non- polluting way to improve the soil fertility and crop production.
\end{abstract}

Keywords: Biological Nitrogen Fixation; sustainability; agriculture; nitrogenase; nif; legume; Rhizobium

\section{Introduction}

\section{Sustainability in Agriculture}

Sustainability is measured as a ratio of input and output by taking into account stock depletion by the economist. In agriculture stocks mean soil, water, renewable energy sources and also environmental quality. Modern agriculture is based upon the principle of maximum output in the short term, with inadequate concern for input efficiency or stock maintenance (Odum, 1989). A trend of 1970s in developed and developing countries is increasing crop yields from $\mathrm{N}$ fertilizer addition (Barker and Chapman, 1988). However, excessive use of $\mathrm{N}$ - fertilizers can cause soil acidification due to the high $\mathrm{N}$ source in soil (Goulding et al., 2016; Sen and
Mukherji 1998). Analysis of several years data on rice yields from studies in Indonesia, Philippines and Thailand shows trends of decline (Pingali et al., 1990).

Therefore to find out a new way to reduce the chemical dependence scientists are engineering crop plants for $\mathrm{N}_{2}$ fixation and they are focused on the biological process BNF (Biological Nitrogen Fixation) for the needs of $\mathrm{N}_{2}$ for crop plant soils.

\section{Nitrogen Fixation}

Nitrogen-fixing organisms can be classified into three categories: free-living $\mathrm{N}$ fixers, associative $\mathrm{N}$ fixers, and symbiotic $\mathrm{N}$ fixers. The last two groups can be found in the 
rhizosphere of legume and non-legume plants. One of the most studied mutualistic relationships of plants and nitrogen-fixing organisms is root nodule symbiosis. This is the most effective in $\mathrm{N}$-fixing (20-300 $\mathrm{Kg}$ ha-1). This is also more important because it involves almost all food and fodder legumes. With a molecular dialogue between the two partners, host plant and nitrogen-fixing organism through the flavonoids and isoflavonoids secreted by the host plant in its rhizosphere, the mutualistic relationship is established. This molecular dialog allows recognition, infection, differentiation of root hair cells, and nodule development (Suzaki et al., 2019).

In the last few years, significant efforts have been made to extend nitrogen fixation to crops particularly in cereals other than legumes (Beyan et al., 2018).

\section{Biological Nitrogen Fixation}

$\mathrm{N}_{2}$ fixed by the BNF process reduces the production cost, Green House gas (GHG) emissions, pollution of surface and ground water. A comprehensive study showed that, efficiency of biologically fixed $\mathrm{N}_{2}$ is greater than the $\mathrm{N}_{2}$ fixed by the $\mathrm{N}$ fertilizers synthetically (Lassaletta et al., 2014). Among all the microorganisms which are involved in BNF process, Rhizobia- legume symbiosis is the most significant and important pathway of the source $\mathrm{N}$ in agricultural field (Herridge et al., 2008).

$\mathrm{N}_{2}$ fixed by the process Rhizobia- legume symbiosis varies depending on many factors like plant species cultivar, residual soil $\mathrm{N}$, environmental conditions etc. Studies shows that, a great amount of $\mathrm{N}_{2}$ is fixed by the perennial forages as compared to annual forages (Havlin et al., 2014).

A study showed that BNF from red clover (Trifolium pratense L.), white clover (Trifolium repens L.) and alfalfa (Medicago Sativa L.) are 252, 102, $465 \mathrm{~kg} \mathrm{~N} \mathrm{ha}^{-1}$ year $^{-1}$. On the other hand, BNF from lentil (Lens culinaris medik.) field pea (Pisum sativum L.) are 52 and $111 \mathrm{~kg}$ $\mathrm{N}$ ha $^{-1}$ year $^{-1}$ respectively (Anglade et al., 2015).

Report says that, legumes remove more soil $\mathrm{N}$ than forages as grain legumes are harvested and removed from the field (Havlin et al., 2014). There are some uncertainties associated with forages with estimating $\mathrm{N}_{2}$ fixation. Sugarcane (Saccharum officinarum L.) and rice (Oryza sativa L.) are some examples. Estimated $\mathrm{N}_{2}$ fixation annually from rice and sugarcane are $5 \mathrm{Tg}$ and $0.5 \mathrm{Tg}$ respectively (Havlin et al., 2014). Biologically and fixed $\mathrm{N}_{2}$ must be transferred to neighbouring non- $\mathrm{N}_{2}$ fixing plant for greater benefits in cropping systems. The proportion of biologically fixed $\mathrm{N}_{2}$ which is transferred to neighbouring plants is highly variable. This range varies $0 \%$ to $73 \%$ depending upon several factors (Fustec et al., 2010).

Several management practices are there that influence BNF process in agricultural system. They are $\mathrm{N}$ - fertilization species genotype and cultivar and seeding ratios (Dhamala et al., 2017). Better management practices can help to improve $\mathrm{N}_{2}$ fixation. An extensive review said that BNF in forage legumes may vary depending on the legume species cultivar, soil nutrient composition, environmental conditions and climate. These various factors influencing BNF process showed varied amounts of $\mathrm{N}_{2}$ fixed by legumes at same locations (Rouquett and Smith, 2010).

$\mathrm{N}_{2}$ fixation is also determined by the strain of Rhizobia. Most Rhizobia strains are highly specialized. Thus, inoculation with right strain of Rhizobia would help to improve $\mathrm{N}_{2}$ fixation (Shantharam and Matoo, 1997).

In cropping system fixed $\mathrm{N}_{2}$ is transferred to other non- $\mathrm{N}_{2}$ fixing crop plants. $\mathrm{N}_{2}$ transfer is accomplished through three main routes, they are decomposition of nodules, exudates of soluble $\mathrm{N}$ compounds and transfer which is mediated by mycorrhizal fungi. $\mathrm{N}$ transfer through nodule decomposition and $\mathrm{N}$ compound exudation is termed as rhizodeposition (Fustec et al., 2010).

A comparative study shows that, though decomposition of roots and nodules to $\mathrm{N}$ transfer have a greater contribution but it is a much slower path than exudates of soluble $\mathrm{N}$ compounds and transfer mediated by mycorrhizae (Thilakarathna et al.,2016). 5.3\% and $3.5 \% \mathrm{~N}$ was rhizo-deposited through the help of root exudates in white clover -perennial 
ryegrass mixture and white clover mono crop within a 3 day period respectively (Thilakarathna et al., 2016). This is an indication that in a short period exudation of a compound meeting $\mathrm{N}$ needs of the crops is produced specially in early growing stage (Thilakarathna et al., 2016).

An intercropping study showed that, in rice and mung bean (Vigna radiata L.) $\mathrm{N}$ transfer increases from 5.4 to $15.7 \%$ when they were inoculated with arbuscular mycorrhizal fungi (AMF) (Li et al., 2009). Another study showed that in fixed $\mathrm{N}_{2}$ transfer from faba bean to wheat (Triticum aestivum L.), proportion of transferred fixed $\mathrm{N}_{2}$ was $50 \%$ when inoculated with AMF while it was only $15 \%$ in uninoculated strand (Wahbi et al., 2016).

Compared to symbiotic nitrogen-fixing bacteria, non-symbiotic bacterial diazotrophs have limited agronomic significance, although their contribution is estimated to about $30 \%$ of total BNF and can be a significant fixed $\mathrm{N}$ source in many terrestrial ecosystems (Smercina et al., 2019). This potential has been proven by the results of how Setaria viridis, inoculated with an ammonia excreting strain of Azospirillum brasilense showed robust growth under nitrogen-limiting conditions (Pankievicz et al., 2015). Recent work has shown that a Mexican maize landrace can fix nitrogen at a rate of up to $82 \%$ when it is associated with a non-symbiotic diazotroph bacteria present in its mucilage of aerial roots. (Van Deynze et al., 2018).

\section{Significant Approaches to Biological $\mathrm{N}_{2}$ Fixation}

Primarily BNF process is only restricted to legumes in agricultural systems but the idea of some researchers to transfer $\mathrm{N}_{2}$ fixing capacity to non- $\mathrm{N}_{2}$ - fixing crops and cereals is one of the most ground breaking thoughts of the decade in the agricultural field. Crops like rice, wheat, maize, sorghum are most important examples. Many studies in recent times have been done to determine the soil microorganism species that are able to fix $\mathrm{N}_{2}$.

Another new research trend in recent years is also very crucial -that is to identify the bacterial gene which encodes the enzyme nitrogenase. Nitrogenase is the enzyme playing a major role in BNF process. The transferring of BNF traits to non- legumes specially cereals still remains elusive (Batista et al., 2019; Griesmann et al.,2018)

The first approach that is taken to engineer new symbioses between cereals and $\mathrm{N}_{2}$ fixing bacteria is by transferring legume plant genes which are essential for the development of root nodule symbiosis in cereals. To release nodule signals a genetic modification is required. As nitrogenase enzyme requires anaerobic environment within the cell for its functions this approach has difficulty to deal with the oxygen toxicity issues (Rogers et al., 2014)

Another important approach that is taken in recent times is to introduce nitrogenase enzyme into crop and cereal plants as plants are able to synthesize $\mathrm{N}_{2}$ for their need on their own without any help of bacterial interventions. But there is also a difficulty present here. Complexity of biosynthesis of this enzyme and oxygen sensitivity of this enzyme is a great challenge for the researchers to implement this approach. Besides, it is still unknown to the scientists that, whether the host crop plants if provided power and energy would sustain nitrogenase catalysis or not (Van et al., 2018).

Another notable work in recent years is the successful transfer and genetic advancements in $\mathrm{N}_{2}$ fixation (nif genes). Gene transfer to $E$. coli, Saccharomyces cerevisiae, plastids of tobacco provides a new ray of hope in this field for the near future to implement these approaches for the betterment of the agricultural systems (Mabrouk et al., 2018).

The recent trend of genetic analysis has allowed a tremendous progress towards $\mathrm{N}_{2}$ fixation in non- legumes. Several years of research in this field has given the world important results like sequencing and database creation of some nitrogenase (nif) genes (nif $\mathrm{H}$ nif $\mathrm{D}$, nif $\mathrm{K}$, nif $\mathrm{E}$, nif $\mathrm{N}$ etc) in 2012 (Gaby et al., 2011). This database contains 32954 sequences which help in better understanding of evolutionary history of the enzyme nitrogenase.

Another comparative study or analysis shows that, symbiotic systems of non- legumes, 
parasponi, legumes and actinorrhizae help to identify the core genetic networks which are underlying root nodule formation and functioning (Wardhani et al., 2019; Mahmud et al., 2020). They also help transferring $N_{2}$ fixing ability to non- legume crops (Santi et al., 2013)

Another work says that, two cellular organelles like mitochondria and root plastids offer a low oxygen environment which is suitable for the nitrogenase enzyme expression in eukaryotes. This is a promising perspective to overcome the obstacles of oxygen sensitivity (Wardhani et al., 2019; Ivleva et al., 2016). These organelles are similar to prokaryotes in terms of gene expression and organization and they also provide high concentration of adenosine5' phosphate which is required for the nitrogenise enzyme activity (Ivlevea et al., 2016).

Another approach in this field in recent years is to improve $\mathrm{N}_{2}$ fixation pathway in diazotrophic, endophytic, associative, symbiotic organisms which are in relationship with plants by using different strategies. Some of these strategies are optimization of carbon supply from root cells to endo-symbiotic bacteria, engineering of $\mathrm{O}_{2}$ - binding proteins to allow aerobic $\mathrm{N}_{2}$ fixation by microsymbionts and improvement of ammonium uptake by plant cells (Dwivedi et al., 2015 ; Ferguson et al., 2018)

Another study shows that, in low $\mathrm{pH}$ environment to overcome the negative effects of $\mathrm{pH}$, plants are treated with flavonoids, NOD factors, phytohormones (Miransari et al., 2006; Suliema et al.,2015). For symbiotic $\mathrm{N}_{2}$ another strategy is applied that is to generate acid tolerant legume cultivars and Rhizobia strains (Pedrosa et al., 2011).

In rice production systems, the nitrogen-fixing symbiotic water fern Azolla in symbiosis with cyanobacterium Anabaena azollae can fix 2-4 $\mathrm{kg} \mathrm{N}$ ha -I day-I (Lumpkin and Plucknett, 1982). Another work shows that, there are other benefits of Azolla that have been recognized which are-

a) weed suppressor, b) $\mathrm{K}$ scavenger from floodwater, c) animal feed, d) fish feed, e) $P$ scavenger in sewage-treatment plants, and $\mathrm{f}$ ) suppressor of ammonia in volatilization. (Watanabe and Liu,1992).

Associative and free-living microorganisms contribute to production of flooded rice production systems (Roger and Ladha, 1992). Approx. $50 \%$ of the $\mathrm{N}$ requirement of this type of crop is fulfilled from the soil $\mathrm{N}$ reserve (Bouldin, 1986). It is maintained through BNF by associative and free-living microorganisms (Koyama and App, 1979). In upland agriculture contribution from non- symbiotic $\mathrm{N}_{2}$ fixation is generally not substantial but $\mathrm{N}_{2}$ fixation to the order of $160 \mathrm{~kg} \mathrm{~N}$ ha - I has been reported for sugarcane (Koyama and App, 1979).

More work has been done in recent years by associating mycorrhiza with BNF (Mukherjee and Sen 2021). It will facilitate the transfer of nitrogen from plants with high fixing potential to low or non-fixing plants as the presence of arbuscular mycorrhiza increase the transfer of symbiotically fixed $\mathrm{N}$ through connection between similar or dissimilar plants (Dellagi et al., 2020).

\section{Conclusion}

This review reveals that Rhizobia- legume symbiosis is the most valuable and major pathway in terms of $\mathrm{N}_{2}$ fixation in agricultural system. Besides this, legume crops (pulses) also contribute largely in $\mathrm{N}_{2}$ fixation. Their effect on the soil $\mathrm{N}$ content after death of the plant helps to cultivate other crops and vegetables. In recent approaches successful transfer and genetic decoding of nif genes is significant.

However, developing countries are still dependent on the chemical $\mathrm{N}$ fertilizers for large scale agricultural production (Burghardt, 2019). For taking full advantage of BNF process in agricultural system researchers are continuously addressing new inventions through collaborative work. Quantitative understanding of the ecological factors which control the performance of BNF systems in the field is essential for the successful adoption of technologies and so is testing of inocula under different soil types and environmental conditions (Soumare et al., 2015)

This review highlights the agro-economic importance of BNF and shows it as a cost 
effective, non- polluting way to improve the soil fertility and crop production. The capacity of engineering to fix $\mathrm{N}_{2}$ in cereals either by themselves or symbiosis with $\mathrm{N}_{2}$ fixing microbes, represent attractive future options that require more intensive and internationally coordinated research efforts.

Agriculture has an enormous environmental footprint, playing a significant role in causing climate change, water scarcity, land degradation, deforestation and other processes; it simultaneously causes environmental changes and in turn gets impacted by those very changes. Developing sustainable food systems, contributes to the sustainability of the human population. For

\section{References}

Anglade, J., Billen, G., Garnier, J. (2015). New relationships for estimating $\mathrm{N}_{2}$ fixation in legumes: Incidence for $\mathrm{N}$ balance of low-input cropping systems in Europe, Ecological Applications 6:1-24.

Barker, R. and Chapman, D. (1988). The Economics of Sustainable Agricultural Systems in developing Countries. Mimeo. Cornell University. Ithaca. NY.

Batista, Marcelo Bueno, Ray Dixon (2019). Manipulating nitrogen regulation in diazotrophic bacteria for agronomic benefit, Biochem Soc Trans 47 (2): 603-614.

https://doi.org/10.1042/BST20180342

Beyan, S.M., Wolde-meskel, E., Dakora, F.D. (2018). An assessment of plant growth and $N_{2}$ fixation in soybean genotypes grown in uninoculated soils collected from different locations in Ethiopia, Symbiosis 75: 189-203.

Bouldin, DR (1986). The chemistry and biology of flooded soils in relation to the nitrogen economy in rice fields. In Nitrogen Economy of Flooded Rice Soils. Eds. S K De Datta and W H Patrick. Martinus Nijhoff Publishers. Dordrecht. The Netherlands pp 1-14.

Burghardt, L.T. (2019). Evolving together, evolving apart: Measuring the fitness of rhizobial bacteria in and out of symbiosis with leguminous plants, New Phytol. 228(1): 28-34.

https://doi.org/10.1111/nph.16045

Dellagi A, Quillere I, Hirel B. (2020). Beneficial soilborne bacteria and fungi: a promising way to improve plant nitrogen acquisition, J Exp Bot. 71(15):4469-4479. doi: 10.1093/jxb/eraa112. example, one of the best ways to mitigate climate change is to create sustainable food systems based on sustainable agriculture. Sustainable agriculture provides a potential solution to enable agricultural systems to feed a growing population within the changing environmental conditions (TAC, CGIAR, 1988).

\section{Acknowledgments}

The authors are thankful to the authorities of Asutosh College, Kolkata, India for granting necessary permission to carry out this work

\section{Conflicts of Interest}

The authors declare no conflict of interest.

Dhamala, N.R., Rasmussen, J., Carlsson, G., Soegaard, K., Eriksen, J.N. (2017). Transfer in three-species grass-clover mixtures with chicory, ribwort plantain or caraway, Plant and Soil 413:217230.

Dwivedi, S.L.; Sahrawat, K.L.; Upadhyaya, H.D.; Mengoni, A.; Galardini, M.; Bazzicalupo, M.; Biondi, E.G.; Hungria, M.; Kaschuk, G.; Blair, M.W.; et al. (2015) Advances in Host Plant and Rhizobium Genomics to Enhance Symbiotic Nitrogen Fixation in Grain Legumes, Adv. Agron. 129 :1-116.

Ferguson, B.J., Mens, C., Hastwell, A.H., Zhang, M., Su, H., Jones, C.H., Chu, X., Gresshoff, P.M. (2018). Legume nodulation: The host controls the party, Plant Cell Environ. 42(1): 41-51.

Fustec, J., Lesuffleur, F., Mahieu, S., Cliquet, JB. (2010). Nitrogen rhizodeposition of legumes. A review, Agronomy for Sustainable Development 30:57-66.

Gaby, J.B.; Buckley, D.H. (2011). A global census of nitrogenase diversity, Environ. Microbiol. 13(7): 1790-1799.

Goulding, K.W.T. (2016). Soil acidification and the importance of liming agricultural soils with particular reference to the United Kingdom, Soil Use Manag. 32: 390-399.

Griesmann M, Chang Y, Liu X, Song Y, Haberer G, Crook MB, Billault-Penneteau B, Lauressergues D, Keller J, Imanishi L, Roswanjaya YP, Kohlen W, Pujic P, Battenberg K, Alloisio N, Liang Y, Hilhorst $H$, Salgado MG, Hocher V, Gherbi H, Svistoonoff S, Doyle JJ, He S, Xu Y, Xu S, Qu J, Gao Q, Fang X, Fu $Y$, Normand $P$, Berry AM, Wall LG, Ané JM, Pawlowski K, Xu X, Yang H, Spannagl M, Mayer 
KFX, Wong GK, Parniske M, Delaux PM, Cheng S. (2018). Phylogenomics reveals multiple losses of nitrogen-fixing root nodule symbiosis, Science 361 : (6398):eaat1743. doi: 10.1126/science.aat1743.

Havlin, J.L., Tisdale, S.L., Nelson, W.L., Beaton, J.D. (2014). Soil Fertility and Fertilizers: An Introduction to Nutrient Management. 8th ed. Vol. 516. Upper Saddle River, NJ: Pearson Prentice Hall pp. 516

Herridge, D.F., Peoples, M.B., Boddey, R.M. (2008). Global inputs of biological nitrogen fixation in agricultural systems, Plant Soil 311: 1-18.

Ivleva NB, Groat J, Staub JM, Stephens M (2016) Expression of Active Subunit of Nitrogenase via Integration into Plant Organelle Genome. PLoS ONE 11(8): e0160951.

https://doi.org/10.1371/journal.pone.0160951

Koyama, T. and App, A. (1979). Nitrogen balance in flooded rice soils. In Nitrogen and Rice. The Intl. Rice Research Inst Los Banos. Philippines pp 95104.

Lassaletta, L., Billen, G., Grizzetti, B., Anglade, J., Garnier, J. (2014) 50 year trends in nitrogen use efficiency of world cropping systems: The relationship between yield and nitrogen input to cropland, Environmental Research Letters 9:1-9.

Li, Y., Ran, W., Zhang, R., Sun, S., (2009). Facilitated Legume nodulation, phosphate uptake and nitrogen transfer by arbuscular inoculation in an upland rice and mung bean intercropping system, Plant and Soil 315:285-296.

Lumpkin, TA and Plucknett, DL (1982). Azolla as a green manure: Use and management in crop production. Westview Tropical Agriculture Series No.5. Westview Press. Boulder. CO pp.225

Mabrouk, Y., Hemissi, I., Salem, I.B., Mejri, S., Saidi, M., Belhadj, O. (2018). Potential of Rhizobia in Improving Nitrogen Fixation and Yields of Legumes, Symbiosis, Everlon Cid Rigobelo, IntechOpen, DOI: 10.5772/intechopen.73495.

Mahmud, K.; Makaju, S.; Ibrahim, R.; Missaoui, A (2020). Current Progress in Nitrogen Fixing Plants and Microbiome Research, Plants 9(1): 97https://doi.org/10.3390/plants9010097

Miransari, M., Balakrishnan, P., Smith, D., Mackenzie, A., Bahrami, H., Malakouti, M., Rejali, F. (2006). Overcoming the stressful effect of low $\mathrm{pH}$ on soybean root hair curling using lipochitooligosacharides, Commun. Soil Sci. Plant Anal. 37(7): 1103-1110.

Mukherjee, R. and Sen, S. (2021). Agricultural Sustainability through Nitrogen Fixation: Approaches and Techniques, Harvest 6(1): 48-55.
Odum, E.P. (1989). Input management of production systems, Science 243: 177-182.

Pankievicz, V.C.S., do Amaral, F.P., Santos, K.F.D.N., Agtuca, B., Xu, Y., Schueller, M.J., Arisi, A.C.M., Steffens, M.B.R., de Souza, E.M., Pedrosa, F.O., et al. (2015). Robust biological nitrogen fixation in a model grass-bacterial association, Plant J. 81: 907-919.

Pedrosa FO, Monteiro RA, Wassem R, Cruz LM, Ayub RA, Colauto NB, et al. (2011) Genome of Herbaspirillum seropedicae Strain SmR1, a Specialized Diazotrophic Endophyte of Tropical Grasses. PLoS Genet 7(5): e1002064.

Pingali, P.L. Moya, P.F. and Velasco, L.E. (1990). The post-green revolution blues in asian rice production - The diminished gap between experiment station and farmer yields, IRRI Social Science Division paper No. 90-01.

Roger, P A and Ladha, J K (1992). Biological $N_{2}$ fixation in wetland rice fields: Estimation and contribution to nitrogen balance, Plant and Soil 141: 41-55.

Rogers, C.; Oldroyd, G.E. (2014). Synthetic biology approaches to engineering the nitrogen symbiosis in cereals, J. Exp. Bot. 65(8): 1939-1946.

Rouquette, F., Smith, G. (2010). Effects of biological nitrogen fixation and nutrient cycling on stocking strategies for cow-calf and stocker programs, The Professional Animal Scientist 26:131-141.

Santi, C.; Bogusz, D.; Franche, C. (2013). Biological nitrogen fixation in non-legume plants. Ann. Bot. 111(5): 743-767.

https://doi.org/10.1093/aob/mct048

Sen,S. and Mukherji,S. (1998). Seasonal effects on nitrogenous compounds in two crop plants, Environment and Ecology 16(4) : 871-874.

Shantharam, S., Mattoo, A.K. (1997). Enhancing biological nitrogen fixation: an appraisal of current and alternative technologies for $\mathrm{N}$ input into plants, Plant and Soil 194:205-216.

Smercina, D.N., Evans, S.E., Friesen, M.L., Tiemann, L.K. (2019). To Fix or Not to Fix: Controls on Free-Living Nitrogen-Fixation in the rhizosphere, Appl. Environ. Microbiol. 85(6):e02546-18. doi: 10.1128/AEM.02546-18.

Soumare, A.; Diop, T.; Manga, A.; Ndoye, I. Role of arbuscular mycorrhizal fungi and nitrogen fixing bacteria on legume growth under various environmental stresses. Int. J. Biosci. 2015, 7, 3146. 
Suliema, S., Tran, L.S.P. (2015). Legume Nitrogen Fixation in a Changing EnvironmentAchievements and Challenges, Sulieman, S., Phan Tran, L.S., Eds. Springer: Cham, Switzerland, pp. 133.

Suzaki, T., Takeda, N., Nishida, H., Hoshino, M., Ito, M., Misawa, F., Handa, Y., Miura, K. Masayoshi, Kawaguchi (2019). Lack of symbiont accommodation controls intracellular symbiont accommodation in root nodule and arbuscular mycorrhizal symbiosis in Lotus japonicus, PLoS Genet. 15(1): e1007966.

TAC CGIAR (1988) Sustainable agricultural production: Implications for International Agricultural Research. CGIAR (Consultative Group on International Agricultural Research) Meeting, Berlin. Germany.

van Deynze A, Zamora P, Delaux P-M, Heitmann C, Jayaraman D, Rajasekar S, et al. (2018) Nitrogen fixation in a landrace of maize is supported by a mucilage-associated diazotrophic microbiota. PLoS Biol 16(8): e2006352.

https://doi.org/10.1371/journal.pbio.2006352 van Velzen, R., Holmer, R., Bu, F., Rutten, L., van Zeijl, A., Liu, W., Santuari, L., Cao, Q., Sharma, T., Shen, D., et al. (2018).Comparative genomics of the nonlegume Parasponia reveals insights into evolution of nitrogen-fixing rhizobium symbioses, Proc. Natl. Acad. Sci. USA 115(20): E4700-E4709.

Wahbi, S., Maghraoui, T., Hafidi, M., Sanguin, H., Oufdou, K., Prin, Y., Duponnois, R., Galiana, A. (2016). Enhanced transfer of biologically fixed $N$ from faba bean to intercropped wheat through mycorrhizal symbiosis, Applied Soil Ecology 107:91-98

Wardhani TAK, Roswanjaya YP, Dupin S, Li H, Linders S, Hartog M, Geurts R, van Zeijl A. (2019). Transforming, Genome Editing and Phenotyping the Nitrogen-fixing Tropical Cannabaceae Tree Parasponia andersonii, J Vis Exp. 18;(150). doi: 10.3791/59971.

Watanabe, I and Liu, C C (1992). Improving nitrogen-fixing systems and integrating them into sustainable rice farming, Plant and Soil 141: 57-67. 